\title{
Judicial Duty Not to Apply EU Law
}

\author{
MIKOŁAJ BARCZENTEWICZ ${ }^{1}$
}

\begin{abstract}
This is a pre-copyedited, author-produced PDF of an article accepted for publication in the Law Quarterly Review following peer review (forthcoming in print in 2017).
\end{abstract}

\begin{abstract}
In several recent cases the Supreme Court has endorsed the idea that there are some general limits to incorporation of European Union law in the United Kingdom. The general limits stem from the Court's interpretation of the European Communities Act 1972, the statute that grounds domestic effect of EU law, construed both in the light of ordinary canons of interpretation and in the light of fundamental principles. This raises the question what are the legal consequences when an EU measure violates one of those limits. In this paper, I propose an answer from the perspective of what a domestic court ought to do. My aim is to develop the legal position emerging from Assange, HS2, Pham, and Miller. I argue that sometimes UK courts are under a duty not to apply EU law. However, the circumstances where this is the case are even more limited than the focus on the general limits of incorporation of EU law may suggest. In particular, fundamental principles of UK law may work to expand the scope of domestic effect of EU law. I want to stress that neither the cited cases, nor the present paper, take a position of hostility towards EU law. The following discussion makes it clear that both EU law and UK law have many devices to avoid conflict and those devices need to be exhausted before a court concludes that it is under a duty not to apply EU law.
\end{abstract}

${ }^{1}$ University College, University of Oxford. Thanks for comments and discussion to Eirik Bjorge, Michael Gordon, Richard Ekins, Ewan Smith and Jeremias Prassl. Contact: www.barczentewicz.com 


\section{TABLE OF CONTENTS}

\section{Introduction 2}

II. The general limits of incorporation of EU law: Assange, HS2, Pham, and Miller

\section{5}

A. Interpreting the ECA 8

1. From Thoburn to Assange, HS2, Pham and Miller: the limited incorporation view $\quad 8$

2. Fundamental principles and parliamentary sovereignty 11

B. Taking stock: the general limits 17

C. The domestic presumption of effect EU law 19

III. Domestic effect of EU law violating the general limits 21

A. The severability argument 22

B. Other grounds for effect of EU law beyond the general limits 26

IV. The EU tools for avoidance of incompatibility 29

A. EU justifications of prima facie incompatible domestic measures 29

B. The scope of the grounds for annulment under Article 263 TFEU 30

C. Lack of UK power to invalidate EU measures; the EU-law power to suspend enforcement of EU measures 31

D. The duty to issue a preliminary reference 33

$\begin{array}{ll}\text { V. Conclusions } & 35\end{array}$

\section{Introduction}

In several recent cases the Supreme Court has endorsed the idea that there are some general limits of incorporation of European Union law in the United Kingdom. ${ }^{2}$ The general limits stem from the

${ }^{2}$ Assange $v$ Swedish Prosecution Authority [2012] UKSC 22; [2012] 2 AC 471 [175]-[176] (Baroness Hale DPSC), [208]-[217] (Lord Mance JSC); $R$ (HS2 Action Alliance Ltd) v Secretary of State for Transport [2014] UKSC 3; [2014] 1 WLR 324 [79] (Lord Reed JSC), [207]-[208] (Lord Neuberger PSC and Lord Mance JSC); Pham $v$ Secretary of State for the Home Department [2015] UKSC 19; [2015] 1 WLR 1591 [90]-[91] (Lord Mance JSC); R (Miller 
Court's interpretation of the European Communities Act 1972 ('ECA'), the statute that grounds domestic effect of EU law, construed both in the light of ordinary canons of interpretation and in the light of fundamental principles of UK law. This raises the question what are the legal consequences when an EU measure violates one of those limits. In this paper, I propose an answer from the perspective of what a domestic court ought to do. My aim is to develop the legal position emerging from Assange, HS2, Pham, and Miller. I argue that sometimes UK courts are under a duty not to apply EU law. However, the circumstances where this is the case are even more limited than the focus on the general limits of incorporation of EU law may suggest. In particular, fundamental principles of UK law may work to expand the scope of domestic effect of EU law. I want to stress that neither the cited cases, nor the present paper, take a position of hostility towards EU law. The following discussion makes it clear that both EU law and UK law have many devices to avoid conflict and those devices need to be exhausted before a court concludes that it is under a duty not to apply EU law.

Given the result of the Brexit referendum and triggering of the Article 50 process by the Prime Minister, the UK will most likely leave the EU within the next two years. However, as long as the ECA 1972 is in force and the UK is a member, the legal position discussed in this paper is not affected. Also, the most probable scenarios for a potential post-Brexit relationship between the UK and the EU would involve some incorporation of EU law, even if indirectly. ${ }^{3}$ More generally, the point made in this paper is applicable a fortiori to all incorporated international law, including the European Convention of Human Rights and other treaties. EU law is currently incorporated in UK law in an unprecedentedly strong way. If there may be a judicial duty not to apply EU law, then the same applies even more forcefully to other international legal regimes. The converse point I make in this paper is also true for other treaties: UK fundamental

and another) $v$ Secretary of State for Exiting the European Union [2017] UKSC 5 [67], [99].

${ }^{3}$ See, e.g., House of Commons Library, Leaving the EU (Research Paper 13/42, 1 July 2013); Ciarán Burke, Ólafur Ísberg Hannesson and Kristin Bansgsund, 'Life on the Edge: EFTA and the EEA as a Future for the UK in Europe’ (2016) 22 European Public Law 69. 
rights and principles may extend the scope of effect in UK law of those other treaties.

The structure of my argument is as follows. I begin by introducing the notion of the general limits of incorporation of EU law in the UK (sec. II). To do that, I discuss the structure of the scheme of incorporation of EU law and the importance of the proper interpretation of the ECA 1972. I present the interpretation suggested by the Supreme Court in Assange, HS2, Pham, and Miller and then defend it against the charge that it is incompatible with parliamentary sovereignty. On this reading of the ECA, the general limits of incorporation leave a sphere of uncertainty. I propose that in practice this uncertainty should be resolved with respect to a strong domestic presumption of effect of EU law in UK law.

Subsequently, in sec. III, I discuss how even when an EU measure clearly violates one of the general limits of incorporation it still may be the case that at least some UK courts have a duty to apply that measure. I argue that domestic principles and doctrines (e.g. the separation of powers, the rule of law, the doctrine of precedent, but also more mundane rules of procedure) may make it the case that UK law gives effect to EU law beyond the general limits of incorporation. Structurally, this point follows Thoburn, HS2, and Miller in recognizing that fundamental principles are highly relevant to interpretation of the ECA 1972. I stress an underappreciated point that fundamental principles may push in both ways: to limit and to extend domestic effect of EU law.

In sec. IV, I show the tools EU law itself possesses to mitigate the risk of a domestically irresolvable conflict between EU law and national law. I discuss the flexibility EU law shows in accommodating constitutional fundamentals of domestic law, as well as the self-controlling aspect of the scope of judicial review of secondary EU law and acts of EU institutions. I accept that in most situations where a UK court may be inclined not to apply EU law it will have a duty first to issue a preliminary reference to the Court of Justice of the European Union ('CJEU'). Also, I stress that even though UK law does not ground a power for domestic courts to invalidate EU law (merely a duty not to apply it in some circumstances), UK courts have an EU-law power to suspend enforcement of EU measures.

Concluding, given the seriousness of the general grounds of nonincorporation of EU law and the safeguards present in UK law and in 
EU law, I reject the view that a court could do something other than to act on the duty not to apply EU law once it concludes that it is all-things-considered under such duty.

\section{The general limits of incorporation of EU law: Assange, HS2, Pham, and Miller}

The general approach the law of the United Kingdom takes towards other legal orders, or to non-UK sources of law, has been described by UK courts as 'dualist'. ${ }^{4}$ On this model, foreign or international law does not affect rights and duties in domestic law unless it has an anchor in domestic law. ${ }^{5}$ That anchor can be as weak and general as, for instance, the principle that the courts ought to develop the common law consistently with international law. ${ }^{6}$ If a foreign or international legal norm does not have an anchor in UK law, then there is no basis for a UK court to help itself to it. Without an anchor, the norm in question is not what UK courts have a permission to recognize as law. However, it is also true that in an important sense, for a domestic court, EU law is not like any other foreign or international legal order. The main anchor of EU law in UK law, statutory incorporation through the European Communities Act 1972 , is stronger and broader than any other recognition of effect of

${ }^{4}$ For mentions of 'dualism', see e.g. Pham (n 2) [80] (Lord Mance JSC); $R$ (Wang Yam) v Central Criminal Court and Another [2015] UKSC 76 [35][38] (Lord Mance JSC); Miller (n 2) [55], [57], [79]. For the general legal position see also, e.g. International Tin Council [1990] 2 AC 418 (500) (Lord Hoffmann); R v Lyons (Isidore Jack) (No 3) [2003] 1 AC 976 [38]-[40] (Lord Hoffmann); Chester v Secretary of State for Justice [2013] UKSC 63; [2014] AC 271 [119] (Lord Sumption JSC).

${ }^{5}$ This characterisation is crude, but it will suffice for my purposes. On the notion of dualism in general, see Pavlos Eleftheriadis, 'Pluralism and Integrity' (2010) 23 Ratio Juris 365, 368-70. See also Philip Sales and Joanne Clement, 'International Law in Domestic Courts: The Developing Framework' (2008) 124 LQR 388.

${ }^{6}$ See, e.g., $R$ (on the application of JS) $v$ Secretary of State for Work and Pensions [2015] UKSC 16; [2015] 1 WLR 1449 [241] (Lord Kerr JSC); Lyons (n 4) [13] (Lord Bingham). 
non-UK law in UK law as emphasized by the Supreme Court in Miller. ${ }^{7}$

Given the ECA's role as the fundamental statutory gateway for domestic effect of EU law, proper interpretation of the legislative choice made by Parliament in enacting the ECA is clearly crucial for the issue of limits of that effect. In this section, I present and accept for the sake of my broader argument the interpretation of the ECA that emerges from recent Supreme Court judgments in Assange, HS2, Pham and Miller. I only defend this reading of the ECA against the charge that it is incompatible with parliamentary sovereignty. I conclude the section by discussing what I see as an important consequence of the strength of incorporation of EU law by the ECA: the presumption of domestic effect of EU law. Both the general limits of EU law and the presumption of effect are important for the later argument.

Before I turn to the issue of interpretation of the ECA, I want to note a controversy that, in the light of recent case law, may now be considered as historical (though it does not mean that it will not return). After HS2, there can be little doubt that, from the perspective of domestic constitutional law, EU law does not affect rights and duties in UK law independent from and in precedence to every domestic statutory rule. ${ }^{8}$ On the rival view, EU law derives its force

${ }^{7}$ The Miller majority made this point so emphatically that their phrasing was arguably overly and unnecessarily strong (e.g. 'EU law [is constituted] as an independent and overriding source of domestic law' and '[EU law has] an overriding supremacy in the hierarchy of domestic law sources') see Miller (n 2) [65], [81], [90]. For criticism of the Miller majority's excessive rhetoric, see Mikolaj Barczentewicz, 'Miller, Statutory Interpretation, and the True Place of EU Law in UK Law' (unpublished manuscript, 2017); Richard Ekins, 'Constitutional Practice and Principle in the Article 50 Litigation' (2017) 133 LQR forthcoming XXX; Mark Elliott, 'Analysis: The Supreme Court's Judgment in Miller' (Public Law for Everyone, 25 January 2017) <https://publiclawforeveryone.com/2017/01/25/analysis-thesupreme-courts-judgment-in-miller/>. For a defence, see Alison L Young, ' $R$ (Miller) $v$ Secretary of State for Exiting the European Union: Thriller or Vanilla?' [2017] European Law Review forthcoming.

${ }^{8}$ See HS2 (n 2) [79] (Lord Reed JSC), [207]-[208] (Lord Neuberger PSC and Lord Mance JSC). For commentary, see Lord Reed JSC, 'EU Law and the Supreme Court' (The Sir Thomas More Lecture, 14 November 2014) <https://www.supremecourt.uk/docs/speech-141114.pdf> accessed 5 
from the common law and may exert it even after repeal of the incorporating provisions of the ECA. ${ }^{9}$ Importantly, even Laws LJ someone who could be seen as sympathetic to the common law view - accepted in Thoburn that there may be limits to the scope of incorporation of EU law in UK law and that such limits are a matter of the proper interpretation of the ECA $1972 .{ }^{10}$ Parliament itself made it clear in section 18 of the European Union Act 2011 ('EUA'), perhaps unnecessarily, that EU law has direct effect in the UK only when it is incorporated by domestic statute. ${ }^{11}$ Most recently, in its Miller judgment the Supreme Court confirmed the crucial dependence of continued domestic effect of EU law on the ECA $1972 . .^{12}$

October 2016; Paul Craig, 'Constitutionalising Constitutional Law: HS2' [2014] Public Law 373; Mark Elliott, 'Constitutional Legislation, European Union Law and the Nature of the United Kingdom's Contemporary Constitution' (2014) 10 European Constitutional Law Review 379; Lady Hale, 'UK Constitutionalism on the March?' (2014) 19 Judicial Review 201 [31]-[34]; Alison L Young and Stephen J Dimelow, 'High Speed Rail, Europe and the Constitution' (2014) 73 CLJ 234; Mikolaj Barczentewicz, “"Constitutional Statutes” still Alive' (2014) 130 LQR 557; Christopher Sargeant, 'Factortame Revisited and the Constitution Reimagined: The UK Supreme Court Take Its First Ride on the HS2 Rail-Line' (2015) 5 The UK Supreme Court Annual Review 157; Michael Gordon, Parliamentary Sovereignty in the UK Constitution (Hart Publishing 2015) 187-91.

${ }^{9}$ For a helpful overview of the rival view, see Graham Gee and Alison L Young, 'Regaining Sovereignty? Brexit, the UK Parliament and the Common Law' (2016) 22 European Public Law 131, 142-43.

${ }^{10}$ For the original point, see Thoburn $v$ Sunderland CC [2002] EWHC 195 (Admin); [2003] QB 151 [69]. For evidence of its acceptance, see HS2 (n 2) [79] (Lord Reed JSC), [207]-[208] (Lord Neuberger PSC and Lord Mance JSC); Pham (n 2) [82], [90] (Lord Mance JSC); see also Craig (n 8) 378-79; Elliott (n 8) 386-87, 389; Sargeant (n 8) 166.

${ }^{11}$ See Paul Craig, 'The European Union Act 2011: Locks, Limits and Legality' (2011) 48 Common Market Law Review 1881, 1903-04; Michael Dougan and Michael Gordon, 'The United Kingdom's European Union Act 2011: "who Won the Bloody War Anyway?"' (2012) 37 European Law Review 3, 8.

${ }^{12}$ Miller (n 2) [60], [66]-[67]. 


\section{A. Interpreting the ECA}

It is now time to consider two possible ways of interpreting the ECA 1972. On the view endorsed in the Thoburn-Miller line of cases, there are general limits to incorporation of EU law through the ECA (sec. II.A.1). It is true that the interpretative method employed to identify some of the general limits of incorporation gives cause for concern from the perspective of parliamentary sovereignty, but I think this concern may be addressed (sec. II.A.2).

1. From Thoburn to Assange, HS2, Pham and Miller: the limited incorporation view

The genealogy of the limited incorporation view adopted most recently by the Supreme Court in Pham and Miller may be traced to the Court of Appeal judgment in the 'Metric Martyrs' case (Thoburn). ${ }^{13}$ In that case, Laws LJ argued that if 'a European measure was seen to be repugnant to a [UK] fundamental or constitutional right' that there could be a question, to be resolved as a matter of UK law, 'whether the general words of the ECA were sufficient to incorporate the measure and give it overriding effect in domestic law'. ${ }^{14}$ The reasoning is based, at least structurally, on the principle of legality as presented by Lord Hoffmann in Simms. ${ }^{15}$

On this view, Acts of Parliament should not be construed as abrogating fundamental principles of profound 'normative importance' (to use Paul Craig's phrase ${ }^{16}$ ) without particularly strong evidence to that effect. When legislating to change the law, Parliament should be taken to be aware of the law as it is at the moment of change and of relative importance of different elements of the law. ${ }^{17}$ Parliament should not be presumed by those tasked with authoritative determination of the content of the law to be reckless,

${ }^{13}$ Pham (n 2); Thoburn v. Sunderland C.C. (n 10).

${ }^{14}$ Thoburn v. Sunderland C.C. (n 10) [69].

${ }^{15} R v$ Secretary of State for the Home Department, ex parte Simms and another [2000] 2 AC 115 (131).

${ }^{16}$ Craig (n 8) 389-90.

${ }^{17}$ See, e.g., Robinson $v$ Secretary of State for Northern Ireland [2002] UKHL 32; [2002] NI 390 [11] (Lord Bingham); AXA General Insurance Ltd \& Others $v$ The Lord Advocate \& Others [2011] UKSC 46, [2011] 3 WLR 871 [152]-[153] (Lord Reed). 
to be like a bull in a china shop, demolishing foundational elements of the constitutional structure left and right by mere implication. ${ }^{18}$ Hence, the courts should conclude that Parliament intended to repeal or to derogate from a legal rule of special normative importance, only when Parliament uses 'express language or necessary implication' (Lord Hoffmann). ${ }^{19}$ There is considerable merit to a cautious approach to this interpretative device, given that it could, when misused, produce results that go against the legislative choice Parliament did make. I come back to this issue later (sec. II.A.2).

Laws LJ repeated the Thoburn point in his later judgments in Youssef and in GI, ${ }^{20}$ as well as extra-judicially. ${ }^{21}$ The Supreme Court took it up for the first time in HS2, citing Thoburn, and then from slightly different perspectives in Pham, citing GI, and in Miller. ${ }^{22}$ In HS2, Lord Reed JSC endorsed the argument that EU law, including the principle of supremacy, derives its effect in UK law through the ECA 1972 and any conflicts between constitutional principles and EU law are 'to be resolved by our courts as an issue arising under the constitutional law of the United Kingdom'. ${ }^{23}$ In the same case, Lord Neuberger PSC and Lord Mance JSC raised the possibility that the ECA does not modify at least some fundamental constitutional principles. $^{24}$

The focus of the Miller judgment was not directed towards the limits of incorporation of EU law, but towards the broad and unprecedented extent of incorporation. Hence, it is not perfectly clear whether the Miller judgment was intended in any way to depart from the position on limits of incorporation expressed in HS2 or in

18 See also Geoffrey Lindell, 'The Statutory Protection of Rights and Parliamentary Sovereignty: Guidance from the United Kingdom?' (2006) 17 Public Law Review 188, 197-98; Jeffrey Goldsworthy, Parliamentary Sovereignty: Contemporary Debates (CUP 2010) 312-13.

${ }^{19}$ Simms (n 15) (131).

${ }^{20} \mathrm{He}$ did so without referring to Thoburn expressly; $R$ (Youssef) $v$ Secretary of State for Foreign and Commonwealth Affairs [2013] EWCA Civ 1302; [2014] QB 728 [26]; $R$ (on the application of GI (Sudan)) $v$ Secretary of State for the Home Department [2012] EWCA Civ 867; [2013] QB 1008 [43].

${ }^{21}$ John Laws, The Common Law Constitution (CUP 2014) 11-14, 64-71.

${ }^{22}$ HS2 (n 2) [208] (Lord Neuberger PSC and Lord Mance JSC); Pham (n 2) [75] (Lord Mance JSC); Miller (n 2) [66]-[67].

${ }^{23}$ HS2 (n 2) [79].

${ }^{24}$ ibid [207]-[208]. 
Pham. The Miller judgment cites both the Thoburn and HS2 statements that I rely on. ${ }^{25}$ However, it only highlights the aspect that continued domestic effect of EU law is tied to continued validity of the ECA 1972 and that it is possible for Parliament to legislate to '[alter] the domestic constitutional status of EU institutions or of EU law' ${ }^{26}$ This is consistent with other cases I discuss. Given positive references to Thoburn and HS2 in Miller, I think it is proper to read Miller as endorsing or at least as not departing from the previous views the Supreme Court expressed on limits of incorporation of EU law.

Not all instances of judicial recognition of general limits of incorporation of EU law involve the fundamental rights and fundamental principles reasoning of Thoburn and HS2. The already mentioned judgment of Lord Mance JSC in Pham, as well as his earlier judgment in Assange, rely on more ordinary methods of statutory interpretation to identify the limits. In Assange, Lord Mance JSC notes that the ECA expressly excludes some parts of the EU Treaties from the scope of incorporation. ${ }^{27}$ Hence, both the excluded Treaty provisions and the measures adopted pursuant to those provisions are not incorporated by the ECA. Express exclusion in the ECA is a general limit of incorporation. Interestingly, Lord Mance JSC rejected some 'back-door' methods of incorporation for those provisions, suggested by the counsel, like e.g. the binding effect of judgments of European courts interpreting the excluded EU law (under section 3(1) of the ECA) or the principle of sincere cooperation (now Article 4(3) of the Treaty on European Union). ${ }^{28}$ Even though it is not my aim here to defend the specific general limits identified in the case law, I wish to note that I consider the position in Assange as eminently plausible.

In Pham, Lord Mance JSC stressed that EU law and acts of EU institutions (including judgments of the CJEU) may be set aside if a UK court concludes that they were ultra vires of the EU Treaties. ${ }^{29}$ It is true that the ECA does not provide for this general limit of incorporation expressly. Hence, I will mention briefly a possible

\footnotetext{
${ }^{25}$ Miller (n 2) [66]-[67].

${ }^{26}$ ibid [67].

${ }^{27}$ Assange v Swedish Prosecution Authority (n 2) [209]-[218].

${ }^{28}$ ibid [212], [215].

${ }^{29}$ Pham (n 2) [90].
} 
interpretative argument underlying the Pham point (Lord Mance JSC did not provide one). The ECA refers to rights, powers, and so on 'created or arising by or under the Treaties' (section 2(1)). Plausibly, there could be an EU measure so clearly ultra vires of EU powers that it could not be considered as 'created or arising by or under the Treaties'. I admit that there is a need for subtlety and restraint on the part of domestic public authorities in identifying EU measures as ultra vires. Lord Mance's JSC discussion in Pham is very attentive to this point. ${ }^{30}$ However, for the purposes of this discussion all that matters is that it is possible for such a case of non-incorporation to arise.

The contrary position, that the ECA incorporates into UK law everything coming from the EU with no limits whatsoever requires a strained and implausible reading of the ECA. The question is not whether the Court of Justice is likely, for example, to uphold EU Commission's decision addressed to the UK placing all UK armed forces under EU command (which would be manifestly ultra vires of the EU Treaties). The question is whether a decision like that would be incorporated in UK law by the ECA 1972. Such result would be so unreasonable and undermine the basic structure of the UK constitution so much (by recognizing unlimited legislative power of the EU), that it cannot be accepted that it is what Parliament intended. ${ }^{31}$ Hence, not everything coming from EU institutions is 'created or arising by or under the Treaties' under section 2(1) ECA. Where exactly the line is to be drawn is a matter I do not need to resolve here.

\section{Fundamental principles and parliamentary sovereignty}

There is an important concern that applies only to the limits of incorporation grounded in the fundamental principles reasoning, but not to other limits like like the ultra vires limit from Pham or express exclusion of parts of EU law in Assange. In his recent book on parliamentary sovereignty, Michael Gordon suggested (writing before Pham) that the obiter dicta from HS2 I referred to above are

\footnotetext{
${ }^{30}$ ibid [90]-[91].

${ }^{31}$ For the relevant principles of statutory interpretation, see, e.g., $R$ (on the application of Edison First Power Ltd) v Central Valuation Officer [2003] UKHL 20; [2003] 4 All ER 209 [116]-[117] (Lord Millett); Bennion on Statutory Interpretation (6th edn, Lexis Nexis 2013) ss. 312-314.
} 
unsound, because the principle of supremacy of EU law 'has domestic effect in UK by virtue of section 2(4) of the ECA' and thus, pace Lord Reed JSC, it could resolve conflicts between UK fundamental constitutional principles and EU law. ${ }^{32}$ This is so as 'the notion of supremacy of EU law is implicit in the instruction which Parliament, via the ECA, has given to the UK courts to give effect to EU law over contrary domestic norms'. ${ }^{33}$ True, 'this instruction can be revoked,' but 'this can only be achieved by further legislation'. ${ }^{34}$ In effect, Gordon claims that the fundamental principles reasoning of Thoburn and HS2 does not ground any general limits of incorporation of EU law. ${ }^{35}$

This is important because it would be a violation of parliamentary sovereignty for a court to refuse to apply EU law inconsistent with some alleged fundamental principle when that principle was not in fact implied by Parliament that enacted the ECA 1972. Despite some judicial and academic voices to the contrary, ${ }^{36}$ 'Parliamentary sovereignty is a fundamental principle of the UK constitution'. ${ }^{37}$ As Lord Mance JSC said in Pham:

unless and until the rule of recognition by which we shape our decisions is altered, we must view the United Kingdom as independent, Parliament as sovereign and European law

\footnotetext{
${ }^{32}$ Gordon (n 8) 188.

${ }^{33}$ ibid.

${ }^{34}$ ibid.

${ }^{35}$ I am grateful to Michael Gordon for clarifying in private conversation that he endorses the other grounds of (what I refer to as) general limits of incorporation discussed in this paper.

${ }^{36}$ See, e.g., HWR Wade, 'Sovereignty-Revolution or Evolution?' (1996) 112 LQR 568; Stuart Lakin, 'Debunking the Idea of Parliamentary Sovereignty: The Controlling Factor of Legality in the British Constitution' (2008) 28 OJLS 709; NW Barber, 'The Afterlife of Parliamentary Sovereignty' (2011) 9 ICON 144. See also Jackson v Attorney-General [2005] UKHL 56; [2006] 1 AC 262 [102] (Lord Steyn); AXA (n 17) [50] (Lord Hope DPSC).

${ }^{37}$ Miller (n 2) [43]. See also, e.g., Richard Ekins, 'Acts of Parliament and the Parliament Acts' (2007) 123 LQR 91, 100-106; Colin Turpin and Adam Tomkins, British Government and the Constitution (CUP 2011) 95-96, 355; Michael Gordon, 'The UK's Fundamental Constitutional Principle: Why the UK Parliament Is Still Sovereign and Why It Still Matters' (2015) 26 King's Law Journal 229.
} 
as part of domestic law because Parliament has so willed. The question how far Parliament has so willed is thus determined by construing the 1972 Act. $^{38}$

Gordon's challenge is as follows:

The idea that the courts might consider reading limits into ECA - even where their intention is to avoid being engaged in challenged to 'the whole legitimacy of Parliamentary democracy as it presently operates' - should therefore be approached with great caution, for to do so would exceed their constitutional authority. ${ }^{39}$

There are good reasons to be very careful about the fundamental rights and fundamental principles type of reasoning in statutory interpretation. ${ }^{40}$ There is a non-trivial risk for judges to encroach on legislative choice when engaged in that sort of argumentation. However, this concern may be addressed. When is the use of fundamental rights and principles reasoning legitimate?

For a court to use a fundamental right or principle to interpret a statute inconsistently with its literal meaning (and, especially, to disapply a statutory provision), the court has to be able to attribute a standing commitment not to abrogate the fundamental right or principle to Parliament that enacted the statute. ${ }^{41}$ For such

${ }^{38}$ Pham (n 2) [80]. In Miller, the Supreme Court stressed that the rule of recognition has not changed; Miller (n 2) [60]. Even those who believe that parliamentary sovereignty has now been qualified in an important sense, endorse the interpretation of the ECA 1972 according to which there are limits to incorporation of EU law; see, e.g., Laws (n 21) 11-14, 64-71; Elliott (n 8) 392.

${ }^{39}$ Gordon (n 8) 188 (footnotes omitted); citing HS2 (n 2) [210].

${ }^{40}$ See, e.g., Goldsworthy (n 18) 315-18; Gordon (n 8) 188-91, 230-35;

Gordon (n 37) 240; Philip Sales, 'Rights and Fundamental Rights in English Law' (2016) 75 Cambridge Law Journal 86, 92, 98-99. But conf. Elliott (n 8) 390-92; Craig (n 8) 384-89.

${ }^{41}$ As Sales LJ suggested, writing extra-judicially about fundamental rights in general:

I suggest that the courts should only identify a fundamental right or interest for the purposes of the principle of legality if it is plausible to infer that Parliament as a collective body itself recognises such a right or interest and may thus be taken to have legislated on the assumption 
attribution to be possible, it must be the case that the right or principle in question was accepted as fundamental by the political community at the moment of enactment of the statute. What is more, it must be that there was an overwhelming consensus over the strength and the scope of application of the right or principle. Consensus, that in a case like the one before the court, the right or principle would apply and be weighty enough to override conflicting considerations.

To give an example: it is not enough that the political community of 1972 accepted the fundamental principle of non-justiciability of the parliamentary law-making process. As Lord Reed JSC noted extra-judicially, '[i]t would be a mistake to think that Parliamentary proceedings are a no-go area for the courts' ${ }^{42}$ If the ECA 1972 is really to be read, as suggested in HS2, as not incorporating EU law that requires courts to pass judgment on the quality of parliamentary scrutiny of a bill, then we must establish that the principle accepted in 1972 covered such a case. It is not required that anyone consciously contemplated this particular case in $1972 .{ }^{43}$ Nevertheless, one needs some evidence that the principle-as-accepted had the scope and strength that would allow it to control interpretation of the statute being interpreted in a way that would make a difference in the case. The Supreme Court in HS2 provides some such evidence, in the form of court judgments and canonical writings (Blackstone). ${ }^{44}$ Importantly, neither case law nor scholarly publications themselves are constitutive of the relevant fact of acceptance of the principle in

that it applies (unless clearly abrogated by the legislation under review).

Sales (n 40) 99. Jeffrey Goldsworthy argued along similar lines:

... if the orthodox justification of the presumptions is taken seriously, the relevant question is what rights were generally accepted as fundamental when the statute in question was enacted.

Goldsworthy (n 18) 306. See also ibid ch 7.III; ch 9.II-III.

${ }^{42}$ Lord Reed JSC (n 8) 9. See also Aileen Kavanagh, 'Proportionality and Parliamentary Debates: Exploring Some Forbidden Territory' (2014) 34 OJLS 443.

${ }^{43}$ Danny Nicol's work suggests that Parliament likely did not form a view on constitutional consequences of the ECA 1972 during the legislative proceedings; see EC Membership and the Judicialization of British Politics (OUP 2001) ch 4.

${ }^{44}$ HS2 (n 2) [203]-[204] (Lord Neuberger PSC and Lord Mance JSC). 
1972. However, they may provide reliable, though defeasible, evidence of what the political community accepted as fundamental.

The approach suggested here may in many cases prove very demanding and it is likely that often there will not be a sufficient evidence of consensus over a fundamental right or principle at the time of enactment of a statute. This will be especially so if the advocates approach this framework seriously and strive to provide the courts with good evidence of a lack of consensus. Without the required consensus over a particular principle, there would be a strong reason to think that the courts are wrong in attributing to Parliament that enacted a statute in question an intent not to derogate from the right or principle. Therefore, there is space for legitimate use of fundamental rights and principles in interpreting the ECA 1972, but - as the Supreme Court noted in HS2 - a much more detailed argument about specific rights and principles is required. ${ }^{45}$

Even if Gordon is correct and the ECA does ground an even more far-reaching domestic principle of supremacy of EU law than the cited case law suggests, it does not follow that UK judges are always to give effect to EU law. Gordon himself gives an example when they could do otherwise. ${ }^{46} \mathrm{He}$ accepts that if, contrary to the conclusions in $H S 2,{ }^{47}$ EU law requires domestic courts to review the quality of parliamentary scrutiny of a bill, then it still may be open for UK courts to refuse to do so by claiming that this is outside of their jurisdiction (which is limited by Article 9 of the Bill of Rights 1688). ${ }^{48}$ It is true, as Lord Mance JSC noted in Chester, that the CJEU said in Kücükdeveci, that a national court is to provide legal protection under EU law to individuals 'within the limits of its jurisdiction' ${ }^{49}$ However, it is still a matter of controversy in EU law whether UK courts are under an EU-law duty to invent a domestic judicial power (like the power to grant interim relief against the Crown in Factortame) in a

\footnotetext{
${ }^{45}$ ibid [208] (Lord Neuberger PSC and Lord Mance JSC).

${ }^{46}$ Gordon (n 8) 188.

${ }^{47}$ HS2 (n 2) [116] (Lord Reed JSC), [209] (Lord Neuberger PSC and Lord Mance JSC).

${ }^{48}$ This is not to say that Gordon does not allow for other scenarios, like the application of Chester along the lines suggested below in sec. III.A.

${ }^{49}$ Chester (n 4) [72], [74]; Case C-555/07 Kücükdeveci [2010] ECR I-00365; [2010] All ER (EC) 867, para 51.
} 
situation when UK law does not provide any judicial procedure to review the level of parliamentary scrutiny and if such scrutiny is required by EU law (see also sec. IV). ${ }^{50}$ Hence, by saying that UK courts could dodge the problem by declaring it non-justiciable, Gordon admits that they could do something EU law arguably requires them not to do. And this amounts to admitting that the domestic principle of supremacy of EU law is much more limited than the correlate EU principle of supremacy (in combination with the EU principle of effectiveness).

Alternatively, perhaps Gordon would prefer to say that EU law principles of supremacy and of effectiveness are still fully incorporated into UK law by the ECA 1972, because all of EU law is so incorporated, but there is a conflict of domestic legal norms. And it happens that in a conflict between some other UK constitutional principles and the domestic principle of supremacy of EU law the latter loses out. Hence, the EU principle of effectiveness is incorporated, but in some cases cannot be given effect by UK courts.

If the interpretation of the ECA 1972 accepted here is correct, i.e. if there may be EU measures that are not incorporated in UK law through the ECA, then that provides a strong reason to think that the duty not to apply EU law is consistent with parliamentary sovereignty. ${ }^{51}$ This point is underestimated, because given the recent talk of the Supreme Court's possible role as a national 'constitutional court' vis-à-vis EU law ${ }^{52}$ and the references the Supreme Court itself

${ }^{50}$ See, e.g., Case C-432/05 Unibet v Justitiekanslern [2007] ECR I-2271, paras 40-47; Case C-583/11 P Inuit Tapiriit Kanatami ECLI:EU:C:2013:625, para 103-104 (' $\ldots$ only if the structure of the domestic legal system concerned were such that there was no remedy making it possible, even indirectly, to ensure respect for the rights which individuals derive from European Union law ...').

${ }^{51}$ I use 'EU measures' as a shorthand for any unit of legal content, including the EU Treaties (and norms contained therein), decisions of EU courts (and distinct points of law made in them), binding acts of other EU institutions (and norms within them), and so on. By employing this stipulative notion I aim to avoid commitment to any conception of individuation of legal norms (of legal content).

${ }^{52}$ See, e.g., 'Oral Evidence Session with Rt Hon. Michael Gove MP, Lord Chancellor and Secretary of State for Justice' (The House of Lords Select Constitution Committee, 2 December 2015) $<$ https://www.parliament.uk/documents/lords- 
made to judgments of the German Constitutional Court, notably in $H S 2,{ }^{53}$ there is a temptation to jump to a conclusion that what must be at stake here is whether the Supreme Court already is or should become a constitutional court with a power to conduct constitutionality review of primary legislation. But this is a non sequitur. Admittedly, the 'constitutional court' parlance is infelicitous. Nevertheless, once one accepts that the gateway for domestic effect of EU law that Parliament opened through the ECA 1972 is a limited one, there is a clear difference between not applying an EU measure that does not fit in the domestic gate and going against Parliamentary intent in a continental-style constitutionality review of Acts of Parliament. Recognition of the existence of a judicial duty not to apply EU law, or even strengthening such duty through new legislation, ${ }^{54}$ do not necessarily impinge on parliamentary sovereignty.

\section{B. Taking stock: the general limits}

It is true that the language used by the ECA 1972 is susceptible to be read literally as providing for effect of all EU measures that purport to be effective domestically. ${ }^{55}$ Section $2(1)$ mentions '[a]ll such rights ...' Section 2(4) talks about 'any enactment' of the domestic lawmaker. Similarly, section 3(1) uses 'all' and 'any' liberally. However, the interpretation adopted in the cited case law does not rely only on literal reading of the ECA, it also employs other methods of statutory interpretation. The general limits of incorporation of EU law identified in the case law may be placed in different places on a plausibility spectrum. It is much harder to resist the Assange conclusion on express exclusions of some Treaty provisions in the ECA than it is to resist particular applications of the fundamental

committees/constitution/AnnualOralEvidence2014-15/CC021215LC.pdf $>$ accessed 15 May 2016, question 9.

${ }^{53}$ HS2 (n 2) [202] (Lord Neuberger PSC and Lord Mance JSC).

${ }^{54}$ Jeff King, 'On the Proposal for a UK Constitutional Court' (UK Constitutional Law Blog, 8 February 2016) $<$ https://ukconstitutionallaw.org/2016/02/08/jeff-king-on-the-proposalfor-a-uk-constitutional-court/> accessed 18 May 2016.

55 Lord Reed JSC mentioned that possibility in his extra-judicial commentary on HS2, see (n 8) 8. 
principles reasoning from HS2 (even if the general interpretative method is sound there is bound to be disagreement over which constitutional principles the ECA does not derogate from).

I do not argue here for a catalogue of general limits of incorporation of EU law in the UK. For the purposes of my argument I accept that Lord Mance JSC is correct in the cited dicta in Assange, HS2 (with Lord Neuberger PSC) and Pham. The following list summarizes the preceding discussion and provides an illustration of the spectrum of the possible general limits of incorporation of EU law based on proposals voiced in case law and in academic literature:

(1) express exclusions in the ECA 1972 (Assange); ${ }^{56}$

(2) fundamental rights and fundamental constitutional principles that Parliament that enacted the ECA 1972 did not intend to derogate from (HS2); ${ }^{57}$

(3) clear violations of the limits of the EU Treaties, even by the CJEU, i.e. the ultra vires limit (Pham); ${ }^{58}$

(4) potential Acts of Parliament introducing EU-incompatible domestic rules 'notwithstanding' the ECA or EU law (Miller); ${ }^{59}$

(5) potential express repeal of the incorporating provisions of the ECA 1972 (Miller). ${ }^{60}$

I adopted a convention of referring to them as 'general' limits of incorporation to reflect the fact that they are not

${ }^{56}$ Assange v Swedish Proscecution Authority [2012] UKSC 22; [2012] 2 AC 471 [209]-[217]. See also Bucnys v Ministry of Justice, Lithuania [2013] UKSC 71; [2014] AC 480 [20] (Lord Mance JSC); Lord Mance JSC, 'Destruction or Metamorphosis of the Legal Order?' (World Policy Conference, Monaco, $14 \quad$ December 2013) 10 $<$ https://www.supremecourt.uk/docs/speech-131214.pdf> accessed 7 May 2016; Lady Hale (n 8) [33].

${ }^{57}$ HS2 (n 2) [207]-[208]; Lord Mance JSC (n 56) 10; Lady Hale (n 8) [31][32].

${ }^{58}$ Pham (n 2) [90].

${ }^{59}$ Miller (n 2) [67]. See also Turpin and Tomkins (n 37) 355-56; Gordon (n 8) 188. For other judicial endorsements of this position see, e.g., Macarthys $v$ Smith [1979] 1 WLR 1189; [1979] ICR 785 (789) (Lord Denning MR); Thoburn v. Sunderland C.C. (n 10) [63] (Laws LJ). But see Craig considering a possibility that the Supreme Court might not give effect to such domestic statute, Craig (n 11) 1905. See also Lady Hale (n 8) [27].

${ }^{60}$ See, e.g., Miller (n 2) [67]; Craig (n 11) 1905. 
all-things-considered limits. In other words, it could be that an EU measure that violates one or more of the general limits is nevertheless still effective in UK law (see sec. III).

Importantly for the main argument of this paper, as Lord Mance JSC stressed in Pham and as the majority of the Supreme Court stated repeatedly in Miller, there is significant breadth and force to the incorporating provisions of the ECA.${ }^{61}$ Also, arguably there is a duty of mutual respect between domestic authorities and EU institutions. ${ }^{62}$ It should be then clear that the limited incorporation reading of the ECA does not entail any position of hostility towards the EU. What is more, this reading is consistent with the view that the ECA grounds a presumption of effect of EU law, to which I now turn.

\section{The domestic presumption of effect EU law}

The relevant provisions of the ECA that provide for effect of EU law in UK law are very broad, though - as Lord Mance JSC recently said regarding section 2(2) ECA - they are 'confined in scope..$^{63}$ I argue that the force of section 2(1) ECA (together with other incorporating provisions) is such that the ECA grounds a presumption that all EU measures that belong to the category of legal acts that are supposed to have effect in domestic law are prima facie effective in UK law (in the sundry ways in which they purport to be effective). In other words, there is a presumption of effect of EU law in UK law. This presumption stems from the ECA and should not be conflated with distinct EU-law presumption of validity of EU measures often stressed in CJEU jurisprudence ${ }^{64}$ or with the EU principle of effectiveness. The domestic presumption of applicability is certainly supported by the EU presumption of validity, but has a distinct ground in the legislative choice of Parliament. This is important, because the EU presumption of validity could not apply beyond the

\footnotetext{
${ }^{61}$ Pham (n 2) [90]; Miller (n 2) [61], [65], [80]-[81].

${ }^{62}$ Pham (n 2) [91].

${ }^{63}$ United States v Nolan [2015] UKSC 63; [2015] 3 WLR 1105 [62].

${ }^{64}$ See, e.g., Case C-137/92P Commission of the European Communities $v$ BASF AG [1994] ECR I-2555, para 48.
} 
scope of incorporation through the ECA (being part of EU law, it is itself in need of incorporation).

Why would we then think that Parliament chose in the ECA to grant the presumption of effect even beyond the scope of the general limits of incorporation? After all, the ECA does not ground the presumption in express terms. The reason is in breadth of incorporating provisions of the ECA, which give EU law an exceptionally significant role in UK legal system. This point was made forcefully, perhaps even too forcefully, by the Supreme Court in Miller. ${ }^{65}$ EU institutions in their legislative, executive and judicial capacity, are - in the virtue of the ECA - authoritative in UK law. Hence, it is implicit in the incorporating scheme that their authoritative actions benefit from a presumption of binding force at least as strong as those of domestic executive bodies. This presumption stands even when an EU measure infringes the limits of incorporation.

How strong is the presumption? There are several possibilities. A strong view would be to see it by analogy with the force of court orders: they can only be set aside in a proper judicial procedure and cannot be disregarded by the addressees even when manifestly erroneous. A moderate view would see the presumption as roughly equivalent to the 'the presumption that delegated legislation is valid unless and until declared invalid'. ${ }^{66}$ This position would in many circumstances have similar consequences as the strong view, but with a qualification that the presumption may not apply (against private persons and public bodies) when the breach of a general limit of incorporation is manifest. ${ }^{67} \mathrm{~A}$ weak view would be that the presumption should be given significant weight in cases of uncertainty as to whether an EU measure violates one of the general limits of incorporation. It is beyond my ambitions in this paper to

\footnotetext{
${ }^{65}$ See $\mathrm{n} 7$ above.

${ }^{66} R v$ Secretary of State for Transport, ex p Factortame (No 1) [1990] 2 AC 85 (142) (Lord Bridge).

${ }^{67}$ By analogy with Boddington v British Transport Police [1999] 2 AC 143 (157)-(158) (Lord Irvine of Lairg LC); F Hoffmann La Roche \& Co AG v Secretary of State for Trade and Industry [1975] AC 295 (366) (Lord Diplock). See also, Smith v East Elloe Rural District Council [1956] AC 736 (769)-(770) (Lord Radcliffe); Interfact Ltd v Liverpool City Council [2011] QB 744 [37] (Lord Judge CJ).
} 
resolve this issue and hence in what follows I will accept the weak option as it is sufficient to develop my point that EU law may be effective beyond the general limits of incorporation.

Concluding, unless a UK court is satisfied that one of the general limits of incorporation has been breached, the court is under a domestic legal duty, grounded ultimately in the ECA 1972 or in another Act of Parliament, to give the kind of effect to the EU measure in question that EU law requires. Arguably, the general limits are indeterminate enough as to leave a considerable scope of uncertainty. The presumption of effect should be an important factor in judicial reasoning in the face of such uncertainty. This is not, however, the whole story. As I argue below, sometimes a court will at least have a permission to apply EU law even when it is beyond the general limits of incorporation.

\section{Domestic effect of EU law violating the general limits}

EU measures that appear not to be effective in UK law because they violate one of the general limits of incorporation may still be in some way binding on a UK court. ${ }^{68}$ I will refer to 'prima facie non-incorporation' to mean a situation where an EU measure violates one of the general limits of incorporation through the ECA 1972 as discussed in the previous section, e.g. when it is incompatible with a UK fundamental constitutional principle. Not every case of prima facie non-incorporation is a case of all-things-considered non-incorporation. In other words, just because a general limit of incorporation is violated by an EU measure, it does not follow that domestic courts are under a duty not to apply the measure.

This does not mean that there are some anchors for binding effect of EU law in UK law that are independent of any statute, and in particular that such independent anchors are to be found in the common law. The principle remains that non-UK law can only affect rights and duties in UK law if there is a statutory anchor. ${ }^{69}$ Note that even the presumption that Parliament legislates in a way consistent

\footnotetext{
${ }^{68}$ On my usage of the notion of 'EU measures', see $\mathrm{n} 51$ above.

${ }^{69}$ See the case law cited in $\mathrm{n} 4$; for a discussion, see Sales and Clement (n 5).
} 
with the UK's international obligations (including the non-incorporated ones) is a presumption of statutory interpretation. Hence, any binding effect of an EU measure that violates one of the general limits of incorporation has to be grounded in a statute. One possibility is that a statute other than the ECA provides for such effect. Another possibility is that the ECA itself, interpreted consistently with certain constitutional principles (e.g. the rule of law), provides for effect beyond the general limits. The second option is particularly important as it suggests that the fundamental rights and fundamental principles reasoning applied to the ECA may push in both directions: to limit and to expand domestic legal effect of EU law. In practical terms, the presumption of effect of EU law counts in favour of accepting that the ECA provides an anchor for domestic effect of any EU measure (it may help to tip the scale).

Having this general framework in mind, I now turn to a discussion of several possible grounds for effect of EU law even when it violates one of the general limits of incorporation. The selection is not supposed to be exhaustive, but merely illustrative. As a particularly good example, I first introduce the severability argument, grounded in separation of powers concerns about the limits of judicial power. Subsequently, I suggest some other possible considerations that may plausibly figure in interpretation of the legislative choice made by Parliament in enacting the ECA.

\section{A. The severability argument}

The severability argument I introduce in this subsection is based on the assumption that in enacting the ECA 1972 Parliament intended to modify the application of the principle of the separation of powers only in favour of effectiveness of EU law. More specifically, if as a result of the ECA the judges have a power to make some choices otherwise reserved for the legislative branch, they only have such power to ensure legal effect of EU law, not otherwise. This matters, because not to apply an EU measure in some cases arguably entails making a choice to change the law that normally is reserved for a legislature. When would this be the case? By analogy with Lord Mance's JSC judgment in Chester, it may be argued that this could happen when some EU legal content that violates the general limits 
of incorporation is not severable from EU legal content that is within those limits. $^{70}$

Chester concerned voting eligibility of prisoners serving life sentences for murder. The discussion that is relevant here comes from the obiter part of Lord Mance's JSC judgment, where he considers the hypothetical situation of EU law granting a right to vote. ${ }^{71}$ According to Lord Mance JSC, even then it would be beyond the powers of a UK court to disapply the statute that prohibits prisoner voting. ${ }^{72}$ No court could simply disapply the prohibition in its entirety, because even according to the far-reaching case law of the European Court of Human Rights (which informs EU law) it is clear that 'a ban on eligibility will be justified in respect of a very significant number of convicted prisoners' ${ }^{73}$ Hence, by disapplying the whole prohibition, a court would be going beyond what is necessary to bring UK law into conformity with a requirement of EU law. And that is something UK courts have no power to do.

It is also not open to a UK court to do anything short of disapplication of the whole ban. ${ }^{74}$ Courts could neither read into the impugned statute some indeterminate criteria of voting eligibility (perhaps something like 'to the extent required by EU law') nor impose their own version of determinate criteria. ${ }^{75}$ The former would go against clear legislative intent (contra legem), which is a limit of conforming interpretation. ${ }^{76}$ The latter would involve the sort of choices that, under the British constitution, are reserved for Parliament. As a result, all that a court could do would be to issue a declaration of incompatibility of UK law with EU law. ${ }^{77}$ It would be a categorically different sort of a declaration of incompatibility from

\footnotetext{
${ }^{70}$ Chester (n 4).

${ }^{71}$ ibid [69]-[83].

${ }^{72}$ ibid [73]-[74].

${ }^{73}$ ibid [73].

${ }^{74}$ ibid [74].

${ }^{75}$ ibid [74].

${ }^{76}$ See, e.g., United States v Nolan (n 63) [14] (Lord Mance JSC); Case C-106/89 Marleasing SA v La Comercial Internacional de Alimentaci n SA [1990] ECR I-4135, para 8.

${ }^{77}$ Chester (n 4) [72].
} 
the one in the EOC case, because it would have no legal effect. ${ }^{78}$ In particular, a Chester declaration could not be relied upon by anyone as authority for setting aside the UK ban on prisoner voting.

By analogy, Chester suggests the following limitation of the duty not to apply an EU measure that violates one of the general limits of incorporation:

(1) not applying the whole measure would also mean not applying the legal content that is within the general limits of incorporation and

(2) severance is impossible.

What I mean by 'severance' is such a construction of an impugned measure that saves all that is within the scope of incorporation and sets aside all that is beyond. On a very schematic example: if EU law requires 100, but it is beyond the limits of incorporation for it to require more than 70 , a domestic court should construe EU law as requiring 70 . The concept of severability is recognised both in UK law and in EU law as limiting the necessity to quash (to annul in full) unlawful delegated legislation (or other legal acts). ${ }^{79}$ Both UK law and EU law apply a test of 'substantial severability'. ${ }^{80}$ UK law also has a test of 'textual severability', also known as the 'blue pencil' test, but it is unclear whether textual and substantial tests have to be both

${ }^{78}$ This follows from what Lord Mance JSC says at [74]: 'Thereafter, it would be for the United Kingdom Parliament to address the position and make such legislative changes as were considered appropriate.' Conf. $R v$ Secretary of State for Employment Ex p Equal Opportunities Commission [1995] 1 AC 1 (27) (Lord Keith of Kinkel).

${ }^{79}$ See, e.g., DPP v Hutchinson [1990] 2 AC 783; HM Treasury $v$ Ahmed [2008] EWCA Civ 1187; [2009] 3 WLR 25 [52]-[53] (Sir Anthony Clarke MR); Case C-425/13 European Commission v Council of the European Union EU:C:2015:483; [2016] 1 C.M.L.R. 11, para 94. See also AW Bradley, 'Judicial Enforcement of Ultra Vires Byelaws: The Proper Scope of Severance' [1990] Public Law 293, 299-300.

${ }^{80}$ DPP v Hutchinson (n 79) (804F) (Lord Bridge of Harwich). Similarly, the CJEU held that:

'Review of whether the contested provisions are severable requires consideration of their scope, in order to be able to assess whether their annulment would alter the spirit and substance of the decision challenged ...'

European Commission v Council of the European Union (n 79), para 94. 
satisfied or whether substantial severability is sufficient. ${ }^{81}$ Severance is only possible when a court can obey fully the power-conferring authority (in our case: the incorporating authority) by giving partial effect to what can be saved from a breach of the power (violation of the general limits of incorporation) without usurping a legislative role.

I am not concerned here with the details of how the tests of severability are supposed to be applied. What is important for my argument, is that if lack of severability may mean that an otherwise non-incorporated EU measure is to be given effect by UK courts, then this must be grounded in a reading of the ECA as consistent with the principle of the separation of powers (and perhaps other fundamental principles). As Lord Bridge and Lord Lowry stress in a landmark case on severability, the courts have no jurisdiction to 'legislate' or to 'modify and adapt the law' ${ }^{82}$ It is easy to see why the severability point applies straightforwardly to Chester: ${ }^{83}$ for a UK court to disapply an Act of Parliament to a greater extent than necessary to bring about conformity of domestic law with EU law, would be a violation of parliamentary sovereignty. However, in the present context, the legislature a domestic court would be going against is not Parliament, but the EU law maker (or an EU institution in the case of non-legislative acts). Hence, even though the argument about courts not having powers to legislate still has some strength, it is not immediately obvious that this sort of a separation of powers concern would be weightier than the reason behind the general limit of incorporation violated in a given case.

The issue of severability shows that there is a need for balancing of fundamental principles in the light of which the incorporating provisions of the ECA are to be interpreted. The separation of powers, especially when it protects encroachment of UK courts on the powers of EU institutions, may lose out in competition with, for example, the force of Parliament's choice expressly to exclude some parts of EU law from the scope of incorporation. This frame helps to

${ }^{81}$ ibid (804) (Lord Bridge of Harwich); (820) (Lord Lowry); HM Treasury $v$ Ahmed (n 79) [53] (Sir Anthony Clarke MR).

${ }^{82}$ DPP v Hutchinson (n 79) (804C) (Lord Bridge of Harwich), (819B) (Lord Lowry).

${ }^{83}$ Note that Lord Mance JSC does not expressly refer in Chester to the notion of severability. 
explain what happened in Assange: the Supreme Court found it possible to sever the non-incorporated legal content of the Treaty on European Union from the part incorporated by the ECA. ${ }^{84}$ Lord Mance JSC rejected arguments of counsel, which may be characterized as severability arguments. For instance, it was argued that not to give effect to some EU legal content that is excluded in the ECA would entail not giving effect to judgments of the CJEU, which are binding under section 3(1) ECA. ${ }^{85}$ The counsel also tried to employ the principle of sincere cooperation in a similar matter. ${ }^{86}$ Lord Mance JSC rejected both points as inconsistent with the correct interpretation of the ECA, both in literal terms and in the light of constitutional principle. ${ }^{87}$

In accordance with my answer to Gordon's worry about fundamental principles reasoning in statutory interpretation and parliamentary sovereignty (sec. II.A.2), the problem of balancing should be approached by asking which principle Parliament considered as weightier when enacting the ECA. Of course, in some, if not many, cases this may be difficult to determine, but not always. As my purpose in this paper is only to provide a general framework to conceptualise the problem of limits of incorporation of EU law, I will not discuss the practical consequences in more detail.

\section{B. Other grounds for effect of EU law beyond the general limits}

Given the important role the principle of the separation of powers has been playing in recent UK constitutional history, there are good reasons to think that in enacting the ECA 1972 Parliament did not intend to derogate from it more than necessary to achieve workable incorporation of European law. The same may be said about the principle of the rule of law and about some other fundamental features of the domestic legal landscape, like the doctrine of precedent. It is not my ambition to provide a comprehensive account of which rules Parliament did not derogate from in the ECA and how exactly are they to be balanced against each other. I merely aim to

\footnotetext{
${ }^{84}$ See $\mathrm{n} 2$.

${ }^{85}$ Assange v Swedish Prosecution Authority (n 2) [212]-[214].

${ }^{86}$ ibid [215].

${ }^{87}$ ibid [212]-[215].
} 
show that it is a potentially fruitful avenue for lawyers and for the courts to explore.

The doctrine of precedent is a good starting point. Domestic hierarchies of precedent and judicial authority have mainly been seen as a problem from the perspective of effectiveness and uniformity of EU law. ${ }^{88}$ In the UK context, it has been argued that the ECA does not derogate from the pre-ECA shape of the doctrine of precedent. ${ }^{89}$ In Dar Al Arkan, Andrew Smith J argued forcefully on the basis of the ECA that the High Court is bound by Court of Appeal precedent, even if the precedent is erroneous in the light of subsequent CJEU case law. ${ }^{90}$ The conclusions that the judge arrived at are hard to square with CJEU case law, but that may merely show that on the Dar Al Arkan view the EU principle of effectiveness as construed by the CJEU is not fully incorporated in UK law.

However, the strength of the doctrine of precedent may also protect domestic effectiveness of EU law. It may constrain the power of a later court to disapply an EU measure accepted as applicable in a previous judgment of a higher court (or of a different panel of the same court, in the case of the Court of Appeal). This example shows that reading the ECA as consistent even with one specific fundamental rule may cut both ways: sometimes providing reasons not to apply an EU measure, but sometimes providing strong reasons to apply. The doctrine of precedent may be particularly significant on the second front. A lower court will not easily depart from, for instance, Supreme Court precedent, even when the lower court is convinced that the Supreme Court got it wrong by holding an EU measure as effective in UK law.

The rule of law may also be seen as pushing interpretation of the ECA is both directions. On one hand, the rule of law grounds a principle of legality according to which exercises of conferred powers

${ }^{88}$ Joined Cases 28-30/62 Da Costa [1963] ECR 31; Case 283/81 CILFIT [1982] ECR 3415, paras. 13-16; Case 146/73 Rheinmühlen-Düsseldorf [1974] ECR 139, para. 4. For recent confirmation, see Case C-173/09 Elchinov [2010] ECR I-8889, paras. 26-32; Case C-416/10 Križan and Others ECLI:EU:C:2013:8, paras. 62-73.

${ }^{89}$ Dar Al Arkan Real Estate Development Co v Al-Refai [2013] EWHC 4112 (QB); [2014] 1 CLC 813.

${ }^{90}$ ibid [55]-[59]. 
must stay within the limits of those powers. ${ }^{91}$ This counts in favour of setting aside, for instance, ultra vires decisions of the CJEU. On the other hand, there is a principle of legal certainty that may strongly support upholding an otherwise suspicious (prima facie non-incorporated) EU measure when the law's subjects have already arranged their affairs in reliance on that measure.

All this is not to say that it is possible, for the purposes of interpreting the ECA, to choose between the principles in the abstract. The point is that the principles need to be balanced when assessing what the ECA requires in respect to a specific EU measure given the relevant context. It may be uncontroversial, for instance, that Parliament that enacted the ECA 1972 did not intend to abrogate the rule-of-law principles. This fact provides a basis for employing the fundamental principles reasoning in interpreting what the ECA requires. However, the application of this kind of reasoning is bound to involve discretion or, perhaps more accurately, judgment. ${ }^{92}$ For example, perhaps there are cases where disruption to legal certainty would be so great that a UK court would be all-things-considered justified in refusing to set aside an ultra vires EU measure.

When a court is faced with an EU measure that violates one of the general limits of incorporation, but is still domestically effective, it may be appropriate for the court to notice the violation in its judgment. Such judicial notice of prima-facie incompatibility would be importantly different from an EOC declaration of incompatibility or from declarations under section 4 of the Human Rights Act 1998. ${ }^{93}$ It would have no legal effect, and hence it could not constitute a breach of EU law. However, given that Parliament is the only UK authority with a power to remedy merely prima facie non-incorporation, it could decide to take action in response to such judicial notice. Parliament could, for instance, bar the domestic effect of the EU measure in question or provide express statutory basis for its binding force in UK law.

\footnotetext{
${ }^{91}$ See, e.g., $R$ (Corbett) v Restormel BC [2001] EWCA Civ 330; [2001] 1 PLR 108 [16] (Schiemann LJ).

${ }^{92}$ Conf. ibid [29] (Sedley LJ).

${ }^{93}$ R. v Secretary of State for Employment Ex p. Equal Opportunities Commission (n 78).
} 


\section{The EU tools for avoidance of incompatibility}

Even though my chief concern in this paper is the legal position under UK law, the picture would be considerably skewed without taking the EU context into account. The purpose of this section is briefly to present the ways in which EU law itself strives to avoid incompatibility with domestic rules of fundamental or constitutional importance. This is salient because at least some potential cases of non-incorporation may be resolved through institutional interaction of UK courts and the CJEU. Also, in procedural terms, I accept that UK courts are under a duty to issue a preliminary reference to the CJEU in all but very few categories of cases of potential non-incorporation.

\section{A. EU justifications of prima facie incompatible domestic measures}

I begin by considering how flexible EU law is in accommodating constitutional variety in domestic law in application of primary EU law. The Treaty on the Functioning of the European Union ('TFEU') grounds the possibility of justifications of non-compliance with some of its core requirements (e.g. freedom of movement of persons), which include 'public policy' considerations (notably in Articles 36, 45, 52 and 65 TFEU). Those provisions tend to be read in CJEU case law and in the literature in the light of the Article 4(2) of the Treaty on European Union ('TEU') that states that the Union shall respect, among other things, 'national identities' of the Member States. ${ }^{94}$ The CJEU recognized among such justifications protection of national languages and the republican character of the state (including the

\footnotetext{
${ }^{94}$ See Lord Reed JSC (n 8) 11-12; Monica Claes and Jan-Herman Reestman, 'The Protection of National Constitutional Identity and the Limits of European Integration at the Occasion of the Gauweiler Case' (2015) 16 German Law Journal 917, 935-36. See also, e.g., Case C-208/09 Ilonka SaynWittgenstein v. Landeshauptmann von Wien [2010] ECR I-13693; Case C391/09 Runevic-Vardyn and Wardyn v. Vilniaus miesto savivaldybés administracija and Others [2011] ECR I-0378; Case C-202/11 Anton Las v. PSA Antwerp NV. [2013] ECLI:EU:C:2013:239.
} 
abolition of nobility). ${ }^{95}$ There is also case law that has reaches similar conclusions but does not reference 'national identity' of a Member State. Probably the best know case of this kind is Omega, where the CJEU held that

Community law does not preclude an economic activity consisting of the commercial exploitation of games simulating acts of homicide from being made subject to a national prohibition measure adopted on grounds of protecting public policy by reason of the fact that that activity is an affront to human dignity. ${ }^{96}$

It is true that when no Treaty-based justification is to be found and the EU Treaties clearly require something of a Member State, then as a matter of EU law it is EU measures that should be given effect, even in precedence over domestic constitutional rules, no matter how fundamental..$^{97}$

\section{B. The scope of the grounds for annulment under Article 263 TFEU}

EU law consists not only of the Treaties themselves, but also of an immense edifice of secondary law. Article 263 TFEU provides for an action for annulment of much of secondary law

on grounds of lack of competence, infringement of an essential procedural requirement, infringement of the Treaties or of any rule of law relating to their application, or misuse of powers.

${ }^{95}$ Case C-208/09 Ilonka Sayn-Wittgenstein v. Landeshauptmann von Wien [2010] ECR I-13693; Case C-391/09 Runevic-Vardyn and Wardyn [2011] ECR I-0378.

${ }^{96}$ Case C-36/02 Omega Spielhallen- und Automatenaufstellungs-GmnH v. Oberbürgermeisterin der Bundesstadt Bonn [2004] ECR I-0960.

97 Case 11/70 Internationale Handelsgesellschaft [1972] C.M.L.R. 255; [1970] ECR 1125, para 3; Case C-409/06 Winner Wetten [2011] 1 C.M.L.R. 21; [2010] ECR I-8015, para 61; Case C-399/11 Stefano Melloni [2013] Q.B. 1067; ECLI:EU:C:2013:107, para 59. 
The scope of the grounds for annulment is rather wide. ${ }^{98}$ This is important not only for actions for annulment, but also when the CJEU is considering a preliminary reference (the Court in practice adopts a unified notion of grounds for invalidity of secondary EU law). ${ }^{99}$ Naturally, secondary EU law may only claim primacy over domestic law if it is valid as a matter of EU law. Hence, it may very well be that an EU measure that violates one of the general limits of incorporation under the ECA 1972 is invalid under the criteria from Article 263 TFEU (not only in the case of ultra vires measures). It would take me too far afield to consider this issue in more depth, but it certainly needs to be part of any practical consideration of potential non-incorporation of secondary EU law in UK law.

\section{Lack of UK power to invalidate EU measures; the EU-law power to suspend enforcement of EU measures}

Consistently with the CJEU's judgment in Internationale Handelsgesellschaft and Foto-Frost, there is no reason to think that the domestic duty not to apply EU law constitutes a power to invalidate EU measures. ${ }^{100}$ There is no basis (and no need) for such power in UK law. This is so even in cases of EU measures that are manifestly ultra vires of the Treaties. There is no domestic need for invalidation, because EU law is not effective in UK law merely because it is considered as valid by EU institutions. EU law is effective in UK law because domestic statutes so provide.

${ }_{98}$ Anthony Arnull, 'Judicial Review in the European Union' in Damian Chalmers and Anthony Arnull (eds), The Oxford Handbook of European Union Law (OUP 2015) 377-78.

${ }^{99}$ ibid.

${ }^{100}$ Case 11/70 Internationale Handelsgesellschaft [1970] ECR 1125, para 3; Case 314/85 Foto-Frost [1987] ECR 4199, para 15. It is a separate issue whether the CJEU is correct to hold this view and it is at least arguable that it is not, especially given the question-begging quality of the CJEU's reasoning. For some reasons to be critical of the CJEU on this issue, see, e.g., Dorota Leczykiewicz, "'Effective Judicial Protection” of Human Rights after Lisbon: Should National Courts Be Empowered to Review EU Secondary Law?' (2010) 35 European Law Review 326, 339-40; Steve Peers and Marios Costa, 'Judicial Review of EU Acts after the Treaty of Lisbon' (2012) 8 European Constitutional Law Review 82, 102 fn 98. 
However, UK courts have an EU-law power to suspend enforcement of EU measures that are unlawful according to EU law. Under EU law, domestic courts have a power to review EU measures to assess their validity and to declare them valid. ${ }^{101}$ If a domestic court concludes its review with a 'serious doubts as to the validity' of an EU measure, then it is not only under a duty to refer the matter to the CJEU, but it also has a power (subject to other conditions) to suspend enforcement of the impugned EU measure while the CJEU proceeds. ${ }^{102}$ Yes, the final determination of validity or invalidity is left to the CJEU, but the power of a domestic court is not trivial. It may even be arguable, though perhaps not very likely, that there is an EU law power, conferred on national courts, to disapply EU measures that are unlawful under EU law in some circumstances when national courts cannot make a reference. ${ }^{103}$

Even when, after the CJEU makes its view known, a UK court is convinced that the CJEU is mistaken and that the CJEU upheld an ultra vires EU measure, all that the domestic court may be required to do is to deny the EU measure domestic effect as breaching the limits of incorporation from the ECA 1972. In a sense, such determination will entail that from the court's perspective, EU institutions, including the CJEU, are mistaken not to see the EU measure in question as invalid. But this is different from claiming a power to invalidate.

I want to stress that only clear or manifest violations of the limits of the EU Treaties are among the general limits of incorporation of EU law (see sec. II). Hence, UK courts ought to give a considerable leeway to the CJEU in deciding whether an EU measure is within the limits of the Treaties or not. Only when it is clear that the CJEU is mistaken, it will be open to a UK court to set aside an EU measure on this basis. Of course, the EU measure in question may violate other general limits of domestic incorporation of EU law and hence it may be that EU-lawfulness of the measure in question is insufficient for effect in UK law.

\footnotetext{
${ }^{101}$ Leczykiewicz (n 100) 339.

${ }^{102}$ See Joined Cases C-143/88 and C-92/89 Zuckerfabrik [1991] ECR I-415; Case C-465/93 Atlanta Fruchthandelsgesellschaft [1995] ECR I-3761.

${ }^{103}$ Leczykiewicz (n 100) 342-48.
} 


\section{The duty to issue a preliminary reference}

The last EU law point I want to raise is the issue of a duty of a domestic court to issue a preliminary reference to the CJEU. According to Article 267 TFEU, all domestic courts may make preliminary references to the CJEU on matters of 'the interpretation of the Treaties' and of 'the validity and interpretation of acts of the institutions, bodies, offices or agencies of the Union'. Article 267 TFEU also provides that national courts of last instance are under a duty to make such reference. ${ }^{104}$ What is important in the light of the main argument in this paper is that many issues of prima facie non-incorporation of EU law in UK law may be resolved through a preliminary reference. The CJEU may declare invalid under EU law an EU measure that happens also to violate one of the general limits of incorporation. Also, when it is a previous interpretation of EU law adopted by EU courts that leads to prima facie non-incorporation in UK law, it may be that the CJEU will reconsider its position. ${ }^{105}$ Not to mention the possibility that the domestic court will end up being convinced by the reasoning offered by the CJEU.

The power and the duty to make references for preliminary rulings, in itself, does not preclude the domestic power of a UK court to disagree with the CJEU. ${ }^{106}$ There are two grounds for such disagreement: (1) the CJEU acting ultra vires of the EU Treaties, (2) the CJEU purporting to bind outside of the scope of section 3(1) of the ECA. On the first point, it may be argued that from the EU-law perspective, domestic courts can never disagree with the CJEU on

${ }^{104}$ For recent judicial treatment, see e.g. Case C-416/10 Križan and Others ECLI:EU:C:2013:8, paras. 62-73

${ }^{105}$ In HS2, Lord Neuberger PSC and Lord Mance JSC said in reference to what they perceived as an error in interpreting EU law by the CJEU that, had it been necessary to decide a case before the Supreme Court, the Justices would have

wished to have the matter referred back to the European Court of Justice for it to reconsider, hopefully in a fully reasoned judgment of the Grand Chamber, the correctness of its previous decision; HS2 (n 2) [189].

${ }^{106}$ On the limits of interpretation and force of Article 267 of the Treaty on the Functioning of the European Union, see Paul Craig and Menelaos Markakis, 'Gauweiler and the Legality of Outright Monetary Transactions' (2016) 41 European Law Review 4, 16. 
points of EU law and it does not matter whether they think the CJEU is acting ultra vires, though this is controversial. ${ }^{107}$ However, the position under UK law is different, as was confirmed in Pham (see sec. II.A.1 above). This is not to say that decisions of the CJEU are never binding when wrong. They are only not binding, in UK law, when they are tainted with a special kind of error, i.e. when they are clearly ultra vires of the EU Treaties. ${ }^{108}$

On the second point, it is true that section 3(1) of the ECA is to be read as providing that determinations of the CJEU are binding on UK courts as to 'as to the meaning or effect of any of the Treaties, or as to the validity, meaning or effect of any EU instrument'. However, decisions of the CJEU are not binding on other matters. In particular, preliminary rulings are not binding on UK courts as to the outcome of a case before a UK court. ${ }^{109}$ It could be that the CJEU goes beyond merely providing interpretation of an EU instrument and gives guidance as to how a domestic court ought to decide a case whilst not taking into account crucial facts of the case. ${ }^{110}$ A UK court may be then required to decide inconsistently with the CJEU's guidance as to the outcome, but consistently with the CJEU's interpretation of EU law.

Crucially, UK law does not, in principle, bar the duty of a domestic court to issue a preliminary reference when it suspects an EU measure to be invalid as a matter of EU law. To the contrary, I propose that UK law grounds a duty to make preliminary references even broader than the one found in Article 267 TFEU as interpreted by the CJEU. Given the strength and breadth of the incorporating provisions of the ECA 1972 (see sec. II.C), it should be accepted that in all cases of prima facie non-incorporation that possibly could be

${ }^{107}$ See Leczykiewicz (n 100) 344 fn 104. For the purposes of the present argument I set the controversy aside.

${ }_{108}$ This conclusion is grounded in interpretation of the ECA 1972, see sec. II.A.1.

${ }^{109}$ HMRC v Aimia Coalition [2013] UKSC 15; [2013] 2 All ER 719 [56] (Lord Reed JSC); see also Lord Reed JSC (n 8) 12-14.

${ }^{110}$ Importantly, guidance as to outcome is not binding on a UK court irrespective of whether the CJEU properly assesses the relevant facts. Of course, the CJEU guidance as to the outcome could be in a sense binding if the case wholly turns on a point of EU law, but this characterization is imprecise (even in such a situation what is binding is interpretation of EU law, not guidance as to the outcome of a domestic case). 
resolved by the CJEU, UK courts (and certainly the Supreme Court) have a duty to make preliminary reference to the CJEU. This is a manifestation of 'the spirit of co-operation' present in UK law that Lord Mance JSC mentions in Pham. ${ }^{111}$ The only cases where this duty may not apply are the cases of non-incorporation caused by express exclusions of parts of EU law in the ECA 1972, repeal of the incorporating provisions of the ECA or 'notwithstanding' legislation. However, if exclusion, repeal or statutory derogation are not universal there may still be issues that interaction with the CJEU could resolve.

\section{Conclusions}

I have argued that the general limits of incorporation of EU law identified in recent case law should be seen as prima facie, because it is possible that an EU measure that violated one or more of them remains effective in UK law. What has not yet been adequately noticed by the courts and the academic literature is that the fundamental constitutional principles reasoning applied to interpretation of the ECA in cases like Thoburn and HS2 may push in a direction of strengthening or broadening of domestic effect of EU law. Fundamental principles are in this context a double-edged sword. Another point I have stressed is that EU law itself has an array of tools to mitigate the risk of incompatibility between EU law and domestic constitutional fundamentals.

Only when all those domestic and European devices are exhausted or inapplicable there may arise an issue of genuine nonincorporation of EU law in UK law. What is a court to do then? One view is to deny the premise: all situations of incompatibility are to be resolved according to the principle of supremacy of EU law. To hold this view would require more bullet-biting than anyone could stomach. For example, it would entail that no matter how manifestly ultra vires a decision of the CJEU would be, it would be binding in UK law (see sec. II.A.1). Hence, there can be little doubt that it

${ }^{111}$ Pham (n 2) [91]. 
sometimes is the case that a court is under a duty not to apply EU law. The already mentioned judgments of Baroness Hale DPSC and Lord Mance JSC in Assange provide a clear and eminently convincing example. ${ }^{12}$ Once an EU measure is beyond one of the general limits of incorporation and there are no legal reasons in UK law that could ground its domestic effect or such reasons are outweighed, then a court is under a duty not to apply EU law. And if a court is under the duty, then this is what the court must do.

Fiat justitia, ruat caelum may sound frightening, but the heavens are unlikely to fall just because UK courts sometimes have a duty not to apply EU law. ${ }^{113}$ It is true that refusal to give effect to an EU measure may have grave political and financial consequences. Among those possible consequences are infringement proceedings under Article 258 TFEU, financial penalties under Article 260 TFEU and even Francovich or Köbler liability. ${ }^{114}$ However, the consequences of setting aside EU law are not always grave, or at least not immediately. Given the practice of the EU Commission and of the CJEU in respect to Articles 258 and 260 TFEU, it is unlikely that any particular court judgment will have infringement proceedings as its consequence. ${ }^{115}$ Instead, the issue is likely to be framed as legislative inaction or erroneous practice in the administration of law. ${ }^{16}$ What this means is that any court, even the Supreme Court, may be reasonably certain that if it refuses to apply EU law, Parliament will have ample time to legislate to remedy the incompatibility (if it so chooses) before the Commission will be satisfied that either of the grounds for invoking Article 258 TFEU has arisen.

In terms of Francovich liability, it is at least arguable that if the EU standard by which UK law could be judged as giving rise to liability is not itself effective in UK law, then there is no reason for UK court to recognize Francovich liability in such situation. The same applies to Köbler liability for judgments of domestic courts of

${ }^{112}$ Assange v Swedish Prosecution Authority (n 2) [175]-[176], [208]-[217].

${ }^{113}$ See, e.g., $R v$ Wilkes (1768) 4 Burr 2527 (2561)-(2562), 98 ER 327 (347) (Lord Mansfield); Rahmatullah $v$ Ministry of Defence [2014] EWHC 3846 (QB) [169] (Leggatt J).

${ }^{114}$ See Turpin and Tomkins (n 37) 355-56.

115 Maciej Taborowski, 'Infringement Proceedings and Non-Compliant National Courts' (2012) 49 Common Market Law Review 1881, 1898-99. ${ }^{116}$ ibid. 
final instance. Finally, disapplication of EU law need not have any consequences of the sort discussed here at all. This is not to say that EU institutions would take no notice of, for example, a well-publicized Supreme Court judgment refusing to apply EU law, but there is clearly a good deal of friction the system can bear.

There may be a question as to whether the result of the Brexit referendum affects the legal position discussed here. Tobias Lock suggested that it may be that EU law will lose 'its bite' in the UK following the vote to leave. ${ }^{117} \mathrm{He}$ asked whether UK courts will 'show the same commitment' to EU law as they have until now. ${ }^{118}$ Without trying to predict what the courts will do in practice, I will make two observations. First, at least the Supreme Court continues to apply EU law without any change of course due to the referendum. ${ }^{119}$ Second, neither the referendum, nor any action of the Crown (short of withdrawing from EU Treaties), can affect the legislative choice that Parliament made by enacting the ECA 1972 . Hence, the UK law that controls application of EU law has not changed.

${ }^{117}$ Tobias Lock, 'A Lame Duck for a Member State? Thoughts on the UK's Position in the EU after the Brexit Vote' <http://verfassungsblog.de/lameduck-united-kingdom-brexit-lock/> accessed 3 July 2016.

118 ibid.

${ }^{119}$ See, e.g., the first Supreme Court judgment applying EU law after the referendum: Goluchowski v Poland [2016] UKSC 36. 